\title{
Rekonfigurasi Jaringan Pada Penyulang Blahkiuh Dengan Menggunakan Metode Particle Swarm Optimization (PSO)
}

\author{
I Made Yudha Anggara Putra ${ }^{1}$, Ngakan Putu Satriya Utama ${ }^{2}$, I. A. Dwi Giriantari ${ }^{3}$ \\ [Submission: 04-10-2018, Accepted: 07-02-2019]
}

\begin{abstract}
Rekonfiguration network is a way to change the switching configuration settings in the network, configuration changes here means closing or opening switches that have a network. This research object is feeder Blahkiuh. Network reconfiguration of feeder Blahkiuh aims to reduce or minimized network power loss. Load flow analysis is done to find the existing network power losses, then optimization using PSO method applied to find the optimum point of intersection which result in reduced power loss in feeder. Research find the optimum power point of intersection is at bus 123, the power loss reduced is $14 \mathrm{~kW}$, from $246 \mathrm{~kW}$ to $232 \mathrm{~kW}$ or decrease of $5,69 \%$.
\end{abstract}

Intisari-Rekonfigurasi jaringan merupakan suatu cara merubah pengaturan konfigurasi switching dalam jaringan, perubahan konfigurasi disini berarti melalukan penutupan atau membuka switch yang terdapat suatu jaringan. Rekonfigurasi jaringan bertujuan untuk meningkatkan kualitas jaringan listrik Penelitian ini membahas mengenai rekonfigurasi jaringan pada penyulang Blahkiuh. Rekonfigurasi pada penyulang Blahkiuh bertujuan untuk memperkecil rugi-rugi daya pada penyulang Blahkiuh. Pertama-tama dilakukan analisis aliran daya untuk mendapatkan rugi-rugi daya awal sebelum dilakukan rekonfigurasi, kemudian dilakukan optimasi untuk mencari titik potong yang tepat pada saluran penyulang Blahkiuh dengan metode PSO. Titik potong merupakan lokasi yang akan dilakukan pemotongan jaringan. Penelitian membahas mengenai rekonfigurasi jaringan pada penyulang Blahkiuh dengan menggunakan metode Particle Swarm Optimization (PSO), dengan titik potong yang didapatkan pada bus 123. Hasil rekonfigurasi yang didapatkan berupa penurunan rugi-rugi sebesar $14 \mathrm{~kW}$. Rugi-rugi awal pada penyulang Blahkiuh sebelum dilakukan rekonfigurasi sebesar $246 \mathrm{~kW}$, setelah dilakukan rekonfigurasi rugi-rugi menjadi $232 \mathrm{~kW}$ atau terjadi penurunan sebesar $5,69 \%$.

Kata Kunci- Rekonfigurasi, jaringan distribusi, penyulang, optimasi, PSO

\section{PENDAHULUAN}

Keperluan masyarakat (konsumen) akan pemakaian listrik terus bertambah pesat seiring waktu. Peningkatan pemakaian listrik perlu diiringi dengan peningkatan kualitas jaringan lisrik selain dari peningkatan sumber listrik. Penggunaan beban (daya) yang besar tanpa diiringi dengan peningkatan kualitas jaringan dapat mengakibatkan dampak kerusakan, baik kerusakan pada peralatan maupun terjadinya rugi-rugi

\footnotetext{
${ }^{1}$ Mahasiswa, Program Studi Teknik Elektro Fakultas Teknik Universitas Udayana, Jl. Kampus Bukit Jimbaran 80361 INDONESIA (tlp: 0361-555225; fax: 0361-4321982; e-mail: yudhaanggara78@gmail.com)

${ }^{2,}{ }^{3}$ Dosen, Program Studi Teknik Elektro Fakultas Teknik Universitas Udayana, Jln. Kampus Bukit Jimbaran 80361 INDONESIA (telp: 0361-703315; fax: 0361-4321; e-mail: ngakansatriya@ee.unud.ac.id)
}

daya (losses) pada sistem jaringan tenaga listrik. Losses pada jaringan dipengaruhi oleh berbagai faktor, salah satu faktor yang berpengaruh adalah resistansi dan reaktansi penyulang. Resistansi disebabkan oleh penghantar pada jaringan listrik. Jarak yang panjang dari jaringan dan diameter penghantar yang kecil akan mengakibatkan resistansi yang besar. Resistansi pada jaringan dapat diminimalisir dengan melakukan penggantian penghantar yang berdiameter kecil dengan perhantar berdiameter lebih besar. Meminimalisir resistansi dapat dilakukan dengan cara melakukan rekonfigurasi jaringan pada penyulang yang panjang dan memiliki jumlah trafo yang banyak. Rekonfigurasi jaringan suatu penyulang bertujuan untuk meminimalisasi adanya rugirugi daya (losses) yang tinggi pada suatu penyulang. Rekonfigurasi juga dapat mencegah adanya beban lebih (overload) dan melakukan penyeimbangan beban (load balancing) pada suatu penyulang tertentu pada sistem jaringan listrik.

Salah satu penyulang yang perlu dilakukan rekonfigurasi jaringan pada area pelayanan PT. PLN (Persero) Rayon Mengwi yakni penyulang Blahkiuh. Penyulang Blahkiuh merupakan suatu penyulang dengan panjang $46 \mathrm{~km}$ dan memiliki jumlah trafo sebanyak 151 buah. Panjang jaringan dan banyak trafo yang terdapat pada penyulang Blahkiuh ini menjadi dasar untuk dilakukan penelitian tentang rekonfigurasi jaringan pada penyulang Blahkiuh. Rekonfigurasi pada penelitian ini bertujuan untuk memotong jaringan pada penyulang Blahkiuh dan menyambungkannya dengan penyulang yang berdekatan

\section{Particle SWAM Optimization (PSO)}

Metode Particle Swarm Optimization (PSO) merupakan suatu bagian metode optimasi metaheuristik. Metode PSO memiliki algoritma yang menyerupai pola pikir dari sekawanan serangga atau pola pikir burung untuk memecahkan suatu permasalahan [1][2]. Metode ini mengunakan pola perilaku suatu individu yang berada dalam kawanan. Setiap individu atau partikel akan berperilaku berdasarkan pada perilaku kawanan atau kelompok, dengan tetap berperilaku berdasarkan kecerdasan sendiri (intelligence).

Metode optimasi Particle Swarm Optimization (PSO) dapat dikatakan sebuah algoritma behaviorally inspired, dimana algoritma behaviorally inspired menggunakan pola perilaku (pikiran) suatu kawanan (swarm intelligence) dalam mencari suatu hasil atau pemecahan permasalahan. Algoritma Particle Swarm Optimization (PSO) merupakan suatu algoritma dasar dari genetika algoritma (GA), dimana algoritma ini dapat dikatakan menjadi dasar dari perkembangan prosedur suatu algoritma [1]. Variable yang yulang...

p-ISSN:1693 - 2951; e-ISSN: 2503-2372 
terdapat pada algoritma PSO, diumpamakan sebagai kawanan dalam kelompok tertentu. Kawanan kelompok memiliki nilai besaran yang konstan dengan letak awal dari partikel berada pada posisi acak (random) pada suatu lokasi tertentu. Karakteristik posisi dan kecepatan dalam metode ini perlu dilakukan asumsi untuk nilai awal masing-masing kecepatan dan posisi. Pencarian posisi terbaik atau nilai fungsi objektif, akan didapatkan berdasarkan pergerakan setiap partikelpartikel pada setiap posisi baik dari sumber sampai ke jaringan (beban). Informasi yang didapatkan oleh masingmasing partikel akan disampaikan ke partikel lainnya, berdasarkan posisi dan kecepatan dari setiap partikel.Contoh yang dapat di ambil dalam sistem distribusi tenaga listrik, misalnya sebuah gardu pada jaringan distribusi.

Gardu pada jaringan distribusi memiliki batasan (range rate) dalam penyaluran tenaga listrik, namun setiap gardu memiliki prosedur penempatan dan proses sebagai berikut :

1. Penempatan sebuah gardu memiliki batasan jarak yang tertentu antara gardu yang satu dengan lainnya.

2. Masing-masing Gardu akan menyalurkan tenaga listrik dari sumber ke masing-masing beban.

3. Sebuah gardu akan mengalirkan listrik dari sumber ke beban dengan menjaga jarak antar gardu pada suatu jaringan distribusi agar tidak terlalu jauh dengan beban.

Dengan demikian penyaluran tenaga listrik dari gardu sampai ke beban akan berdasarkan pada beberapa faktor[1], diantaranya :

1. Kohesi - penyaluran tenaga listrik.

2. Separasi - tidak terlalu dekat.

3. Alignment - berdasarkan beban.

Rule (proses) untuk gardu apabila dikembangkan berdasarkan metode Particle Swarm Optimization (PSO) akan memiliki model sebagai berikut[1].

1. Sebuah gardu apabila berada dekat beban atau konsumen maka proses penyaluran energi akan lebih mudah. Hal ini dikarenakan jarak yang mesti dilalui oleh partikel pendek, sehingga untuk mencapai suatu hasil tidak memerlukan waktu yang lama.

2. Masing-masing gardu akan menyalurkan tenaga listrik ke beban terdekat, namun untuk gardu yang terletak jauh akan menyalurkan tenaga listrik ke beban melalui atau melewati beberapa komponen yang terdapat pada jaringan distribusi.

3. Peralatan (komponen) yang terdapat di dalam jaringan distribusi akan yang mempengaruhi kualitas penyaluran energi listrik.

Algoritma ini, selanjutkan akan diimplementasikan ke dalam sebuah program untuk mencapai sejumlah iterasi yang telah ditentukan. Iterasi yang dilakukan bertujuan untuk mencari posisi terbaik suatu partikel yang sesuai dengan kriteria dari fungsi objektif. Iterasi dilakukan sampai jumlah iterasi yang ditetapkan telah tercapai atau iterasi juga dapat berhenti berdasarkan pada ketentuan-ketentuan awal sesuai dengan hasil iterasi yang diingankan.
Penelitian ini menggunakan persamaan fitness function pada Particle Swam Optimization (PSO) sebagai berikut.

$$
\sum_{i=1}^{n} \sum_{j=1}^{n}\left(\alpha_{i j}\left(P_{i} P_{j}+Q_{i} Q_{j}\right)+\beta_{i j}\left(Q_{i} P_{j}+Q_{i} P_{j}\right)\right)[2]
$$

Dengan,

$$
\begin{aligned}
& \alpha_{i j}=\frac{r_{i j}}{\left|v_{i}\right|\left|v_{j}\right|} \cos \left(\delta_{i}-\delta_{j}\right) \\
& \beta_{i j}=\frac{r_{i j}}{\left|v_{i}\right|\left|v_{j}\right|} \sin \left(\delta_{i}-\delta_{j}\right)
\end{aligned}
$$

$P_{i}$ dan $P_{j}$ : Daya aktif pada bus $i$ dan $j$.

$Q_{i}$ dan $Q_{j}$ : Daya reakrif pada bus $i$ dan $j$.

$V_{i}$ dan $V_{j}$ : Tegangan bus $i$ dan $j$.

$\delta_{i}$ dan $\delta_{j}:$ Sudut dari bus $i$ danj.

$r_{i j} \quad:$ Tahanan antar bus $i$ dan $j$.

Dari pemetaan fitness function yang dilakukan, fungsi tujuan yang dicapai sebagai berikut.

$$
P_{L}=\sum_{k=1}^{n} \operatorname{Loss}_{k}
$$

Dimana,

$\begin{array}{ll}\text { Loss }_{k} & \text { : rugi-rugi pada titik } \mathrm{k} \\ n & \text { : bus yang digunakan } \\ P_{L} & \text { : rugi-rugi daya nyata pada system }\end{array}$

Persamaan 4 merupakan suatu fungsi rugi-rugi daya. Rugirugi daya aktif $\left(\Delta P_{P}\right)$ merupakan perbedaan nilai yang ditetapkan $\left(P_{P}^{\text {spec }}\right)$ dengan nilai yang dihitung $\left(P_{P}^{\text {cale }}\right)$ atau yang lebih dikenal dengan istilah residu daya[3], yang diperlihatkan pada persamaan berikut.

$$
\begin{gathered}
\Delta P_{p}=P_{p}^{\text {spec }}-P_{p} \text { calc } \\
\Delta P_{p}=P_{P \text { spec }}-\left|V_{p}\right| \sum_{q=1}^{n}\left|V_{q}\right|\left[G_{p q} \cos \left(\delta_{p}-\delta_{q}\right)+B_{p q} \sin \left(\delta_{p}-\delta\right)\right]
\end{gathered}
$$

Particle Swarm Optimization (PSO) pada penelitian ini bertujuan untuk mencari titik potong yang optimal pada penyulang. Hasil titik potong kemudian akan dilakukan rekonfigurasi jaringan. Rekonfigurasi jaringan distribusi merupakan suatu upaya yang dilakukan untuk meminimalisir adanya rugi-rugi daya pada suatu jaringan dengan cara pengaturan ulang sistem jaringan, konfigurasi dilakukan dengan cara merubah konfigurasi switching dalam jaringan, perubahan konfigurasi disini berarti melalukan penutupan atau membuka switch yang terdapat suatu jaringan[4][5]. Rekonfigurasi juga dapat dilakukan dengan upaya pemotongan jaringan dan penyambungan jaringan pada jaringan distribusi yang berdekatan[6]. Rekonfigurasi jaringan bertujuan untuk meningkatkan proses penyaluran energi listrik dari sumber ke konsumen, sehingga dengan rekonfigurasi peningkatan mutu penyaluran listrik kepuasan pelanggan akan lebih terjamin[7]. Rekonfigurasi dilakukan tanpa melakukan perubahan yang besar pada jaringan yang sudah ada, perubahan yang signifikan akan menimbulkan pembiayaan (cost) yang besar. 
Majalah Ilmiah Teknologi Elektro, Vol. 18, No. 1, Januari - April 2019

DOI: https://doi.org/10.24843/MITE.2019.v18i01.P02

Rekonfigurasi jaringan pada umumnya dilakukan untuk memperbaiki kualitas sistem jaringan kelistrikan. Tujuan utama dari dilakukannya rekonfigurasi tidak lain adalah untuk, meminimalisir adanya losses pada jaringan dan melakukan penyeimbangan beban.

\section{METODOLOGI}

Dalam penelitian ini diperlukan beberapa data-data pendukung, baik berupa data jaringan, beban maupun gambar jaringan pada penyulang Blahkiuh dan sekitarnya. Data dalam pembahasan penelitian ini bersumber dari data PT. PLN (Persero) Area Bali Selatan, PT. PLN (Persero) Rayon Mengwi, studi literatur dan sumber-sumber lainnya. Data-data yang dipergunakan pada penelitian ini mengunakan data skunder.

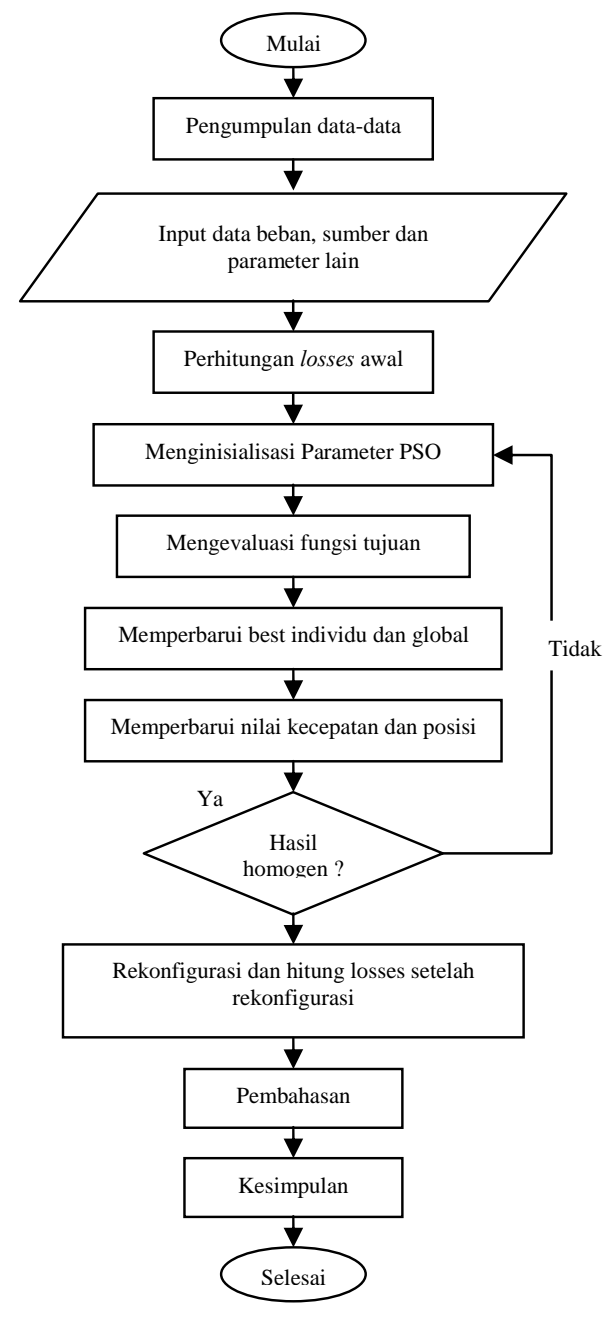

Gambar 1 : Flowchart Rekonfigurasi Jaringan

A. Analisis Data

Penelitian ini memiliki beberapa langkah-langkah penelitian untuk mencapai hasil rekonfigurasi jaringan pada penyulang Blahkiuh diantaranya yakni :

1. Menghitung besar rugi-rugi daya awal pada penyulang Blahkiuh.

2. Melakukan rekonfigurasi dengan menggunakan metode Particle Swam Optimization (PSO) guna mendapatkan lokasi titik potong berdasarkan data hasil losses awal yang didapatkan.

3. Menghitung rugi-rugi daya setelah melakukan rekonfigurasi.

4. Melakukan perbandingan besar penurunan daya yang didapatkan dari hasil rekonfigurasi yang telah dilakukan pada penyulang Blahkiuh dengan penyulang yang ada di sekitar yakni penyulang Payogan.

B. Alur Analisis

Untuk mempermudah melakukan penelitian, beberapa langkah dari penelitian ini dibuatkan alur analisis. Alur analisis dari penelitian yang dilakukan secara sistematis seperti terlihat pada gambar : 1 .

\section{IV.HASIL DAN PEMBAHASAN}

\section{A. Perhitungan Rugi-Rugi Daya Sebelum rekonfigurasi}

Untuk mengetahui besar rugi-rugi daya yang terdapat pada penyulang Blahkiuh dan penyulang sekitarnya, yang terdekat (penyulang Payogan), maka perlu dilakukan analisis aliran daya dengan menggunakan software pendukung. Analisis aliran daya (load flows) dilakukan dengan menggunakan metode Newton-Raphson.

Analisis aliran daya ini menggunakan beberapa data yang telah didapatkan seperti data tegangan, sudut tegangan, besar sumber, data beban pada masing-masing penyulang, besar resistansi dan reaktansi pada jaringan Data yang akan dimasukkan sebelumnya perlu dilakukan perubahan bentuk supaya dapat dibaca oleh load flow, seperti pemberian kode bus pada data dan penentuan $M V A$ Base yang akan digunakan. MVA Base berguna untuk mempermudah perhitungan losses, sehingga untuk MVA Base pada penelitian ini menggunakan 100 MVA. Kode bus yang akan digunakan yakni dengan kode 1 dan 0 . Untuk kode bus 0 merupakan kode bus untuk bus beban. Bus beban (load bus) parameter yang diketahui berupa daya aktif (P) dan daya reaktif (Q). Kode 1 merupakan kode untuk slack bus, untuk slack bus parameter utama yang diketahui berupa sudut tegangan dan tegangan. Sehingga bentuk data yang akan diolah dan dibaca oleh program load flow dan pemberian kode bus akan terlihat sebagai berikut.

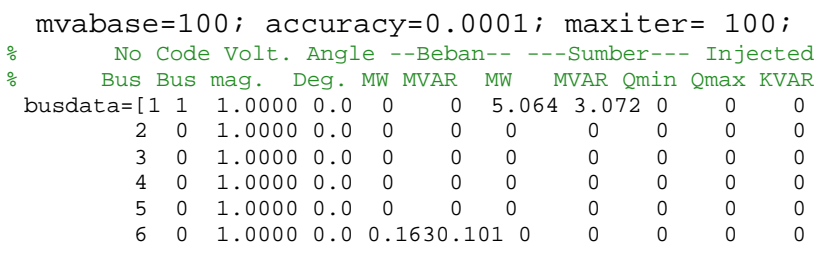

I Made Yudha Anggara Putra:Rekonfigurasi Jaringan Pada Penyulang... 
]; $\begin{array}{lllllllllll}322 & \odot & 1.0000 & 0.0 & 0.0120 .008 & \odot & 0 & 0 & 0 & 0\end{array}$

$\%$ Line code

\begin{tabular}{|c|c|c|c|c|c|c|}
\hline No & Code & $\mathrm{R}$ & $x$ & $1 / 2 B$ & \multicolumn{2}{|c|}{$=1$ for lines } \\
\hline Bus & Bus & $\mathrm{pu}$ & $\mathrm{pu}$ & $\mathrm{pu}$ & $\begin{array}{l}>1 \text { or } \\
\text { at }\end{array}$ & $\begin{array}{l}<1 \mathrm{tr} \text {. tap } \\
\text { bus nl }\end{array}$ \\
\hline linedata $=$ & $=[1$ & 2 & $\bullet .01189$ & 0.40555 & ๑. $00 \odot \odot \odot \odot$ & 1 \\
\hline & 3 & 2 & 0.01153 & 0.00736 & 0.0000000 & 1 \\
\hline & 4 & 3 & 0.17238 & 0.24440 & ๑.๑००००० & 1 \\
\hline & 5 & 4 & 0.04968 & 0.07043 & ๑.0๑०००० & 1 \\
\hline & 5 & 6 & 19.99998 & 45.82578 & 0.000000 & 1 \\
\hline & 117 & 322 & 39.99998 & 91.65153 & $\odot .0 \odot \odot \odot \odot \odot$ & 1 \\
\hline
\end{tabular}

];

Data yang sudah dirubah ke listing program kemudian di run. Hasil perhitungan load flow didapatkan besar rugi-rugi daya pada masing-masing penyulang. Rugi-rugi daya pada penyulang Blahkiuh dan Payogan sebelum dilakukan rekonfigurasi didapatkan sebagi berikut.

TABEL1

LOSSES AWAL PADA MASING-MASING PENYULANG

\begin{tabular}{|c|c|c|}
\hline No. & Penyulang & $\begin{array}{c}\text { Losses } \\
\text { kW }\end{array}$ \\
\hline 1 & Penyulang Blahkiuh & 246 \\
\hline 2 & Penyulang Payogan & 72 \\
\hline
\end{tabular}

\section{B. Penentuan Titik Potong}

Perhitungan rugi-rugi daya awal pada penyulang Blahkiuh akan di baca atau sebagai input untuk menentukan lokasi titik potong dengan menggunakan metode Particle Swarm Optimization (PSO). Titik potong pada penelitian ini berupa titik lokasi bus pada saluran distribusi. PSO akan mencari lokasi saluran dengan losses pada saluran yang akan dipotong berdasarkan pada fitness function yang telah dibuat. Fitness function mencari lokasi titik potong berdasarkan pada nilai losses pada jaringan.

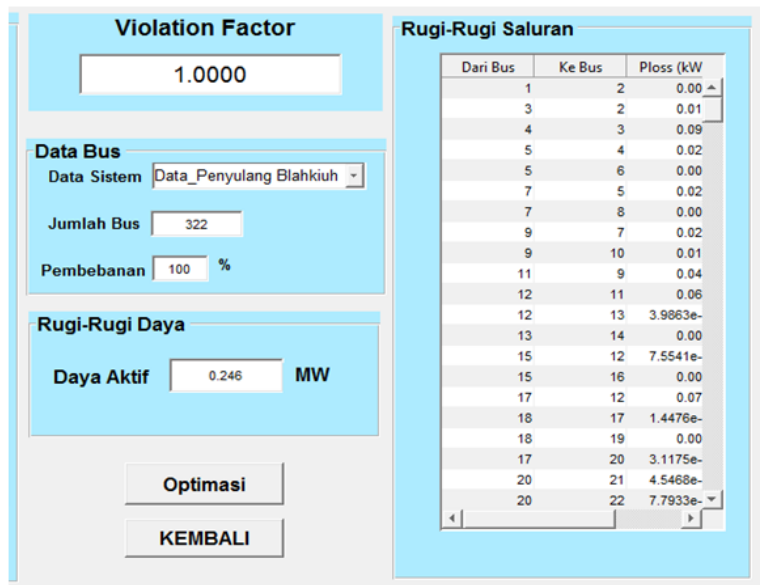

Gambar 2 : Hasil Perhitungan Rugi-Rugi Daya (Input dari PSO)

Program yang telah di buat pada software dan semua data yang di input ke listing program kemudian dijalankan. Nilai besar rugi-rugi daya aktif dari 322 bus yang terdapat pada penyulang Blahkiuh akan keluar dari userinterface yang telah dibuat. Rugi-rugi daya dari running program load flow didapatkan sebesar $246 \mathrm{~kW}$. Losses yang didapatkan kemudian akan menjadi input untuk proses penentuan titik potong yang akan dipasang Load Break Switch (LBS). Titik potong didapatkan dengan langkah mengklik tombol optimasi. Optimasi penempatan LBS menggunakan maksimal 10 iterasi. Penentuan titik potong yang akan muncul dari program yang telah berjalan berupa kurva. Hasil kurva lokasi titik potong yang didapatkan terlihat pada gambar : 3 .

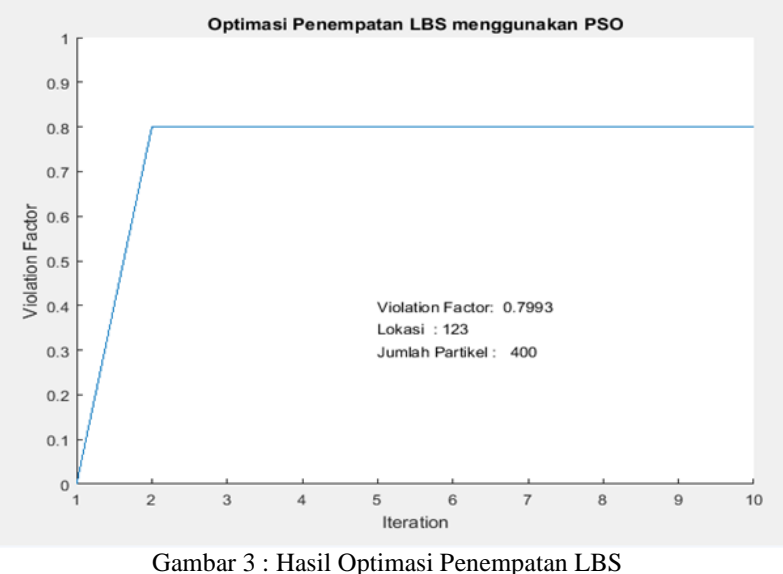

Gambar : 3 memperlihatkan kurva penempatan optimasi titik potong untuk Load Break Switch (LBS) pada penyulang Blahkiuh pada bus 123. Lokasi titik potong yang didapatkan kemudian dilakukan pengecekan letak bus 123 pada single line diagram penyulang Blahkiuh, yang selanjutnya dari hasil yang didapatkan ini akan dilakukan rekonfigurasi pada bus 123 dengan penyulang yang berdekatan. Lokasi titik potong dari bus 123 pada penyulang Blahkiuh terlihat pada gambar : 4.

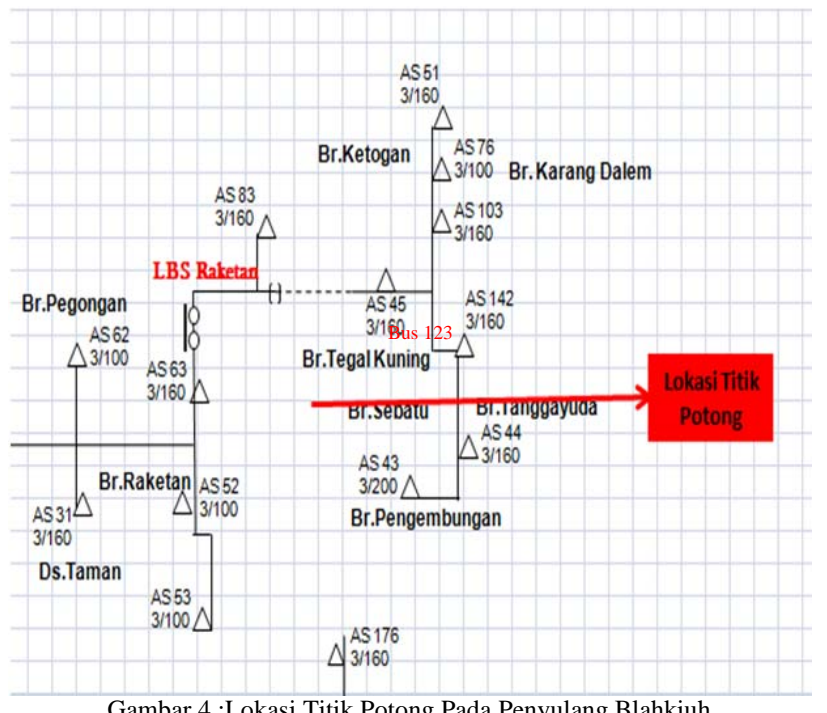

Gambar 4 :Lokasi Titik Potong Pada Penyulang Blahkiuh 
Majalah Ilmiah Teknologi Elektro, Vol. 18, No. 1, Januari - April 2019

DOI: https://doi.org/10.24843/MITE.2019.v18i01.P02

Lokasi titik berada pada bus 123, dimana bus 123 terdapat di daerah banjar Tanggayuda. Single line diagram pada lokasi bus 123 memperlihatkan posisi ujung timur dari penyulang Blahkiuh. Penyulang yang berdekatan yang terdapat pada titik potong dalam area pelayanan Bali Selatan tidak memungkinkan untuk melakukan manuver rekonfigurasi sesama area pelayanan, maka optimasi dilakukan dengan rekonfigurasi penyulang Blahkiuh dengan penyulang Payogan. Melihat dari area yang dilayani berbeda, dimana penyulang Blahkiuh merupakan area pelayanan Bali Selatan sedangkan penyulang Payogan dilayani oleh area Bali Timur, maka untuk titik 123 hanya dilakukan pemotongan dan disambungkan ke penyulang Payogan tanpa dipasangkan dengan Load Break Switch (LBS).

Titik potong yang telah diketahui pada lokasi 123, memperlihatkan untuk gardu AS 44 dan AS 43 dilakukan pemotongan dan di sambungkan ke penyulang Payogan. Gardu AS 44 dan AS 43 kemudian disambungkan ke penyulang Pyogan kemudian dilakukan perhitungan losses kembali. Perhitungan losses setelah rekonfigurasi dilakukan dengan cara yang sama seperti perhitungan losses sebelum rekonfigurasi. Hasil perhitungan dari losses setelah rekonfigurasi penyulang Blahkiuh dengan penyulang Payogan didapatkan hasil sebagaimana yang terlihat pada tabel 2 .

TABEL 2

HASIL RUGI-RUGI DAYA SETELAH DILAKUKAN REKONFIGURASI

\begin{tabular}{|c|c|c|}
\hline No. & Nama Penyulang & $\begin{array}{c}\text { Rugi-Rugi Daya } \\
(\mathbf{k W})\end{array}$ \\
\hline 1 & Penyulang Blahkiuh & 232 \\
\hline 2 & Penyulang Payogan & 74 \\
\hline
\end{tabular}

Hasil perhitungan losses setelah dilakukan rekonfigurasi pada penyulang Blahkiuh, didapatkan hasil bahwa terjadi penurun losses. Losses yang didapatkan pada penyulang Blahkiuh sebelum dilakukan rekonfigurasi sebesar $246 \mathrm{~kW}$ sedangkan setelah dilakukan rekonfigurasi terjadi penurunan menjadi $232 \mathrm{~kW}$. Penurunan rugi-rugi daya pada penyulang Blahkiuh sebesar $14 \mathrm{~kW}$ atau jika di persentasekan sebesar 5,69\% penurunan rugi-rugi pada penyulang Blahkiuh setelah dilakukan rekonfigurasi dari rugi-rugi awal sebelum direkonfigurasi.

\section{KESIMPULAN}

Setelah dilakukan penelitian dengan menggunakan metode PSO untuk merekonfigurasi jaringan penyulang Blahkiuh dengan mengalihkan bus 123 ke penyulang Payogan dapat menurunkan rugi-rugi daya dari $246 \mathrm{~kW}$ menjadi $232 \mathrm{~kW}$ atau sebesar 5,69\%. Kedepannya diharapkan penelitian dapat dilakukan dengan menggunakan metode optimasi yang lain guna mendapatkan perbandingan yang lebih baik.

\section{REFERENSI}

[1] Santosa, Budi dan Willy, Paul. Metoda Mataheuristik Konsep dan Implementasi. Surabaya: Guna Widya. 2011.

I Made Yudha Anggara Putra:Rekonfigurasi Jaringan Pada Penyulang...

2] Fawnia, Rosalind. “Analisis Penyambungan Distributed Generation Guna Meminimalkan Rugi-Rugi Daya Menggunakan Metode Particle Swarm Optimization (PSO)". Jurnal Teknologi Elektro, Vol. 16, No.03,September-Desember. 2017.

[3] Suhadi dan Tri Wrahatnolo. Teknik Distribusi Tenaga Listrik Jilid I. Jakarta: Departemen Pendidikan Nasional. 2008.

[4] Tanjung, Abrar. "Rekonfigurasi Sistem Distribusi 20 kV Gardu Induk Teluk Lembu Dan PLTMG Langgam Power Untuk Mengurangi Rugi Daya Dan Drop Tegangan”. Jurnal Sains, Teknologi dan Industri, Vol. 11, No. 2, Juni. 2014.

[5] Zebua, Osea. "Rekonfigurasi Jaringan Distribusi Untuk Meminimisasi Rugi-Rugi Pada Penyulang Kabut Di Gardu Induk Teluk Betung Menggunakan Metode Binary Particle Swarm Optimization (BPSO)”. Jurnal Nasional Teknik Elektro, Vol. 5, No. 1, Maret. 2016.

[6] Kurniati, Sri dan A, Sudirman S. Analisis Rugi-Rugi Daya Jaringan Distribusi $20 \mathrm{kV}$ Pada Sistem PLN Kota Kupang. Jurnal Media Elektro, Vol. V, No. 2. 2017.

[7] A. , Arismunandar, dan Kuwahara S. Teknik Tenaga Listrik, Jilid II. Jakarta: PT. Pradnya Paramitha. 1993.

[8] A. , Arismunandar, dan Kuwahara S. Teknik Tenaga Listrik, Jilid III. Jakarta: PT. Pradnya Paramitha. 2004. 


\section{[HALAMAN INI SENGAJA DIKOSONGKAN]}

